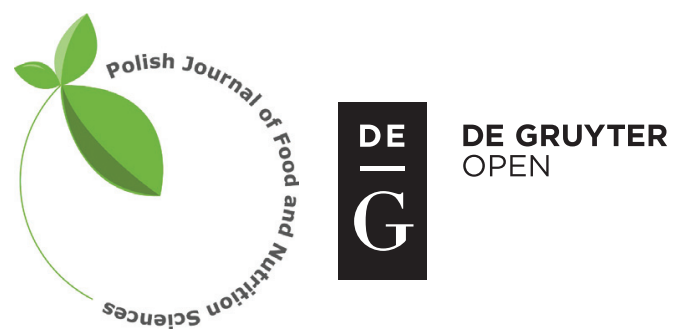

Pol. J. Food Nutr. Sci., 2018, Vol. 68, No. 1, pp. 73-81 DOI: $10.1515 /$ pjfns-2017-0005 http://journal.pan.olsztyn.pl

Original research article

Section: Food Chemistry

\title{
Characterization of Active Compounds of Different Garlic (Allium sativum L.) Cultivars
}

\author{
Konrad A. Szychowski i*, Kamila Rybczyńska-Tkaczyk², Katarzyna Gawet-Bęben ${ }^{3}$, Michat Świeca ${ }^{4}$, \\ Monika Karaśs, Anna Jakubczyk ${ }^{4}$, Magdalena Matysiak ${ }^{5}$, Urszula E. Binduga' ${ }^{1}$, Jan Gmiński ${ }^{1}$ \\ ${ }^{1}$ Department of Public Health, Dietetics and Lifestyle Disorders, \\ University of Information Technology and Management in Rzeszow, Sucharskiego 2, 35-225 Rzeszow, Poland \\ ${ }^{2}$ Department of Environmental Microbiology, Laboratory of Mycology, \\ University of Life Sciences, Leszczyńskiego 7, 20-069 Lublin, Poland \\ ${ }^{3}$ Department of Cosmetology, University of Information Technology and Management in Rzeszow, \\ Sucharskiego 2, 35-225 Rzeszow, Poland \\ ${ }^{4}$ Department of Biochemistry and Food Chemistry, University of Life Sciences, Skromna 8, 20-704 Lublin, Poland \\ ${ }^{5}$ Department of Molecular Biology and Translational Research, \\ Institute of Rural Health, Lublin, Poland, Jaczewskiego 2, 20-090 Lublin, Poland
}

Key words: garlic, Allium sativum, antioxidant, chromatography, ion chelation, cytotoxicity

Garlic (Allium sativum L.) has a reputation as a therapeutic agent for many different diseases such as microbial infections, hypertension, hypercholesterolaemia, diabetes, atherosclerosis and cancer. Health benefits of garlic depend on its content of biologically-active compounds, which differs between cultivars and geographical regions. The aim of this study was to evaluate and compare the biological activity of aqueous extracts from nine garlic varieties from different countries (Poland, Spain, China, Portugal, Burma, Thailand and Uzbekistan). Antioxidant properties were evaluated through free radical scavenging (DPPH $\left.{ }^{*}, \mathrm{ABTS}^{-+}\right)$and ion chelation $\left(\mathrm{Fe}^{2+}, \mathrm{Cu}^{2+}\right)$ activities. The cytotoxicity of garlic extracts was evaluated in vitro using Neutral Red Uptake assay in normal human skin fibroblasts. The obtained results revealed that garlic extracts contained the highest amount of syringic and $p$-hydroxybenzoic acids derivatives. The lowest $\mathrm{IC}_{50}$ values for $\mathrm{DPPH}{ }^{\bullet}, \mathrm{ABTS}^{*+}$ scavenging and $\mathrm{Cu}^{2+}$ chelating ability were determined in Chinese garlic extracts (4.63, 0.43 and $14.90 \mu \mathrm{g} / \mathrm{mL}$, respectively). Extracts from Spanish cultivar Morado and Chinese garlic were highly cytotoxic to human skin fibroblasts as they reduced cellular proliferation by $70-90 \%$. We showed diverse contents of proteins and phenolic components in garlic bulbs from different varieties. The obtained results could help to choose the cultivars of garlic which contain significant amounts of active compounds, have important antioxidant properties and display low antiproliferative effect and/or low cytotoxicity against normal human skin fibroblast BJ.

\section{INTRODUCTION}

The native land of Garlic (Allium sativum L. Alliaceae) is Middle Asia where it was used as a medicine since 2700 BC [Petrovska \& Cekovska, 2010]. Garlic has been used throughout history for both culinary and medical purposes [Meriga et al., 2012]. The plant has the opinion of a remedy for viral, bacterial and fungal infections. Moreover garlic and garlic extracts are used as supplementary therapeutic agents in human diseases such as hypertension, hypercholesterolaemia, diabetes, atherosclerosis, and different types of cancers [Amagase, 2006; Bhandari, 2012]. It is generally believed that health-related properties of a fresh garlic extract are mostly attributed to the content of sulfur compounds [Amagase, 2006; Bhandari, 2012]. However, the most common non-sulfur compounds of garlic including polyphenolics also display health benefits [Beato et al., 2011; Bhandari, 2012]. Interest-

\footnotetext{
* Corresponding Author: E-mail: konrad.szychowski@gmail.com (K.A. Szychowski, PhD)
}

ingly, some studies attribute biological properties of garlic to the synergistic action and proportion of different phytochemicals contained in a garlic clove [Bhandari, 2012].

A number of health benefits of garlic depend on its antioxidant activity. Garlic extracts and components obtained from garlic bulbs were shown to prevent oxidative modification of DNA, protein and lipids by scavenging reactive oxygen species (ROS), increasing the cellular antioxidant enzymes and enhancing glutathione levels inside the cells [Belloir et al., 2006; Kohda et al., 2013]. Phenolic compounds are powerful antioxidants abundant in fruit, vegetable and spices. Several epidemiological studies indicate a significant correlation between a high intake of plant polyphenols in diet and preventive effects in terms of cancer, cardiovascular and neurodegenerative diseases [Arts \& Hollman, 2005]. In contrast to several garlic sulfur compounds, phenolics are more stable and might be extracted from fresh, frozen or dried plant samples [Dai \& Mumper, 2010]. Interestingly, contents of biologically-active compounds in garlic vary between cultivars grown in differ- 
ent geographical regions [Beato et al., 2011; Gorinstein et al., 2005].

The aim of the presented study was to compare the properties of nine garlic cultivars, grown in different world regions such as Poland ('Harnaś' variety), Spain ('Castano', 'Morado' and 'Violetta' varieties), China, Portugal, Burma, Thailand, and Uzbekistan, as potential ingredients of dietary supplements and pharmaceuticals. Aqueous garlic extracts were compared for the content of phytochemicals with, including phenolics, protein and peptides and their potential biological activity as free radical scavenging activity and pro-oxidative ion chelating. The cytotoxic potential of garlic extracts in humane fibroblast in vitro was evaluated as well.

\section{MATERIALS AND METHODS}

\section{Chemicals}

ABTS $^{*}$ (2,2'-azino-bis (3-ethylbenzothiazoline-6-sulphonic acid)), DPPH' (2,2-diphenyl-1-(2,4,6-triphenyl-hydrazyl)), ferrozine (sodium salt of 3-(-pirydyl)-5,6-diphenyl-1,2,4-triazolidynic acid), potassium persulfate 99\%, Dulbecco's Phosphate Buffered Saline (DPBS), $3.3 \mathrm{mg} / \mathrm{mL}$ Neutral Red solution and Bradford reagent were purchased from Sigma-Aldrich. Eagle's Essential Minimum Medium (EMEM) with L-glutamine was purchased from ATCC. Fetal bovine serum (FBS) was purchased from Invitrogen. All other chemicals and reagents were of analytical grade.

\section{Preparation of aqueous extracts from raw garlic}

Polish 'Harnaś', Spanish 'Castano', 'Morado', 'Violetta', and Chinese garlic varieties were kindly donated by Krzysztof Markiewicz from Markie-Pol Company, Dąbrówka Wielka, Poland. The other garlic varieties were purchased in local markets in Portugal, Thailand, Burma, and Uzbekistan. Aqueous extracts from raw garlic were prepared according to a previously described procedure [Lemar et al., 2002]. Briefly, $10 \mathrm{~g}$ of fresh garlic cloves were homogenized on ice with $100 \mathrm{~mL}$ of DPBS buffer for $30 \mathrm{~min}$. Afterwards, the homogenates were centrifuged at $3900 \times \mathrm{g}$ for $10 \mathrm{~min}$. The collected supernatants were passed through a $0.22 \mu \mathrm{m}$ filter (Merck Millipore) to sterilize the extracts. The extracts were stored in aliquots at $-20^{\circ} \mathrm{C}$.

\section{Determination of peptide and protein contents}

The content of peptides was determined by the trinitrobenzenesulfonic acid (TNBS) method using L-leucine as the standard [Adler-Nissen, 1979]. The content of protein in garlic extracts was evaluated using the Bradford method [Bradford, 1976]. Protein content was determined in garlic extracts based on the BSA standard curve and displayed as $\mathrm{mg} / \mathrm{mL}$.

\section{Determination of the total phenolic compounds}

The content of total phenolic compounds in garlic extracts was determined using the Folin-Ciocalteu reagent according to Singleton and Rossi's method [1965]. Absorbance of the sample was measured at $740 \mathrm{~nm}$. The total phenolics content was calculated based on the gallic acid standard curve. The content of total phenolics was expressed as $\mathrm{mg} / \mathrm{mL}$ of gallic acid equivalents (GAE).

\section{Quantitative and qualitative analysis of total phenolics content}

Garlic extract samples were analyzed with a Varian ProStar high-performance liquid chromatograph according to the Świeca \& Baraniak [2014]. The mobile phase consisted of $4.5 \%$ acetic acid (solvent $\mathrm{A}$ ) and 50\% acetonitrile (solvent B); the solvents were applied at a flow rate of $0.8 \mathrm{~mL} / \mathrm{min}$. At the end of the gradient, the column was washed with $50 \%$ acetonitrile and equilibrated to the initial condition for $10 \mathrm{~min}$. The gradient elution was used as follows: $0 \mathrm{~min}, 92 \%$ A; $30 \mathrm{~min}, 70 \%$ A; $45 \mathrm{~min}, 60 \% \mathrm{~A} ; 80 \mathrm{~min}, 60 \% \mathrm{~A} ; 82 \mathrm{~min}$, $0 \%$ A; 85 min, 0\% A; 86 min, 92\% A; and 90 min, $92 \%$ A. Detection was carried out at 270 and $370 \mathrm{~nm}$. Spectrum analysis and comparison of spectra retention times with those of the standard compounds enabled identifying the phenolics in a sample. Quantitative determinations were carried out with the external standard calculation, using calibration curves of the standards [Swieca \& Baraniak, 2014].

\section{DPPH' radical-scavenging activity}

$\mathrm{DPPH}^{\cdot}$ radical scavenging was analyzed according to Brand-Williams et al. [1995]. Each garlic extract $(1 \mathrm{~mL}$, conc. $2.5,5.0,10.0$ and $20.0 \mathrm{mg} / \mathrm{mL}$ ) was mixed with $1 \mathrm{~mL}$ of $25 \mathrm{mmol} / \mathrm{L} \mathrm{DPPH}$ solution in $96 \%$ ethanol. Following 30-min incubation at room temperature, the absorbance of the sample was measured at $\lambda=515 \mathrm{~nm}$ using $96 \%$ ethanol as a blank sample. Ascorbic acid (AA) was used as a positive control. The percentage of $\mathrm{DPPH}^{*}$ scavenging was calculated for each sample based on the equation:

$$
\% \text { of } \mathrm{DPPH}^{\cdot}=[1-(\mathrm{As} / \mathrm{Ac})] \times 100 \%
$$

where: As - absorbance of the sample; Ac - absorbance of the control (DPPH* solution). The $\mathrm{IC}_{50}$ value was defined as an effective concentration of total phenolics that is required to scavenge $50 \%$ of radical activity.

\section{ABTS $^{\cdot+}$ radical-scavenging activities}

Scavenging of $\mathrm{ABTS}^{*+}$ free radical was evaluated according to Re et al. [1999]. The garlic extract $(20 \mu \mathrm{L}$, conc. 0.125 , $0.5,1.0,1.5$ and $2.5 \mathrm{mg} / \mathrm{mL}$ ) was mixed with $980 \mu \mathrm{L}$ of a diluted $\mathrm{ABTS}^{*+}$ solution and incubated for $10 \mathrm{~min}$. The decrease in $\mathrm{ABTS}^{*}+$ absorbance was measured at $\lambda=734 \mathrm{~nm}$ using distilled water as a blank. Ascorbic acid (AA) was used as a positive control. The percentage of $\mathrm{ABTS}^{\cdot+}$ scavenging was calculated based on the equation:

$$
\% \text { of } \mathrm{ABTS}^{\cdot+}=[(1-(\mathrm{As} / \mathrm{Ac})] \times 100 \%
$$

where: As - absorbance of the sample; Ac - absorbance of the control (ABTS ${ }^{-+}$solution). The $\mathrm{IC}_{50}$ value was defined as an effective concentration of total phenolics that is required to scavenge $50 \%$ of $\mathrm{ABTS}^{\cdot+}$ radicals.

\section{$\mathrm{Fe}^{2+}$ chelation assay}

The chelation of iron (II) ions by garlic extracts was measured according to Decker \& Welch [1990]. The absorbance was subsequently measured at $\lambda=562 \mathrm{~nm}$. EDTA was used as a positive control. The chelation activity was calculated as 
the percentage of ferrozine $-\mathrm{Fe}^{2+}$ complex formation inhibition, using the following formula:

$$
\% \text { of } \mathrm{Fe}^{2+}=[1-(\mathrm{As} / \mathrm{Ac})] \times 100 \%
$$

where: As - absorbance of the sample; Ac - absorbance of the control. The $\mathrm{IC}_{50}$ value was defined as an effective concentration of total phenolics in the extract from $1 \mathrm{~g}$ of raw garlic which is required to chelate $50 \%$ of $\mathrm{Fe}^{2+}$ ions.

\section{$\mathrm{Cu}^{2+}$ chelation assay}

Copper chelating activity was measured according to the method of Torres-Fuentes et al. [2011]. EDTA was used as a positive control. Copper ion chelating capability was calculated according to the formula:

$$
\% \text { of } \mathrm{Cu}^{2+}=[1-(\mathrm{As} / \mathrm{Ac})] \times 100 \%
$$

where: As - absorbance of sample; Ac - absorbance of control. The $\mathrm{IC}_{50}$ value was defined as the amount of total phenolics in the extract from $1 \mathrm{~g}$ of raw garlic that is required to chelate $50 \%$ of $\mathrm{Cu}^{2+}$ ions.

\section{Cell culture experiments}

\section{Cell culture and treatment}

Normal human skin fibroblasts BJ (ATCC CRL-2522) were maintained in EMEM (ATCC 30-2003) supplemented with $10 \% \mathrm{FBS}$ at $37^{\circ} \mathrm{C}$ in a humidified atmosphere with $5 \%$ $\mathrm{CO}_{2}$. BJ cells were seeded in a density of $3 \times 10^{3}$ per well on a 96-well plate and grown in EMEM supplemented with $10 \%$ FBS prior to the experiment. The culture medium was changed prior to treating the cells with the garlic extracts selected to this study. In the experiment, the cells were grown in EMEM supplemented with $1 \% \mathrm{FBS}$ in the presence of $1 \mathrm{mg} / \mathrm{mL}$ garlic extracts.

\section{Neutral Red Uptake assay and cell morphology}

Neutral Red Uptake assay determines the accumulation of the Neutral Red dye in the lysosomes of viable, uninjured cells [Repetto et al., 2008]. Following $48 \mathrm{~h}$ of culture with the studied garlic extracts, the number of viable cells in each well was estimated using the Neutral Red Uptake Test. The cells were incubated in the presence of a Neutral Red solution for $2 \mathrm{~h}$. Afterwards, each well was washed with $150 \mu \mathrm{L}$ of DPBS and incubated with $100 \mu \mathrm{L}$ of an acidified ethanol solution ( $50 \%$ ethanol, $1 \%$ acetic acid, $49 \% \mathrm{H}_{2} \mathrm{O}$ ) for $5 \mathrm{~min}$ at room temperature, on a rotating platform. The absorbance was measured at a wavelength of $540 \mathrm{~nm}$ using a FilterMax F5 Multi-Mode microplate reader (Molecular Devices, Corp., Sunnyvale, CA, USA). The morphology of the cells was analyzed microscopically using a Nikon Eclipse inverted microscope and documented using an Invenio 5SII camera.

\section{Statistical analysis}

The data are presented as the means \pm SD of four independent experiments. Each treatment for cytotoxicity was repeated eight times within the experiment; the total number of repetitions was $n=32$. Each treatment for the content of phytochemicals and their biological properties was repeated three times $n=12$. The average of the samples was used for statistical analyses. Statistical analysis was performed on the original results. Where possible, the results were presented as percentage of controls. The data were analyzed via one-way analysis of variance (ANOVA) followed by the Tukey's multiple comparison procedure.

\section{RESULTS}

\section{Content of protein, peptides and phenolic compounds in aqueous extracts from garlic cultivars}

Contents of phytochemicals in aqueous garlic extracts differed significantly. The main differences were noted in the content of peptides (Figure 1A). The highest content of these compounds was detected in Chinese and Spanish 'Castano' extracts, i.e. $6.12 \mathrm{mg} / \mathrm{mL}$ and $4.87 \mathrm{mg} / \mathrm{mL}$, respectively. Polish 'Harnaś', Spanish 'Morado' and Uzbek cultivars were characterized by peptide contents between 2.98 and $3.29 \mathrm{mg} / \mathrm{mL}$. As in the case of peptides, the highest content of protein was found in Chinese and Spanish 'Castano' extracts, namely: $2.80 \mathrm{mg} / \mathrm{mL}$ and $2.81 \mathrm{mg} / \mathrm{mL}$, respectively. The lowest amounts of protein and peptides contained extracts from Spanish 'Violetta' cultivars (Figure 1A).

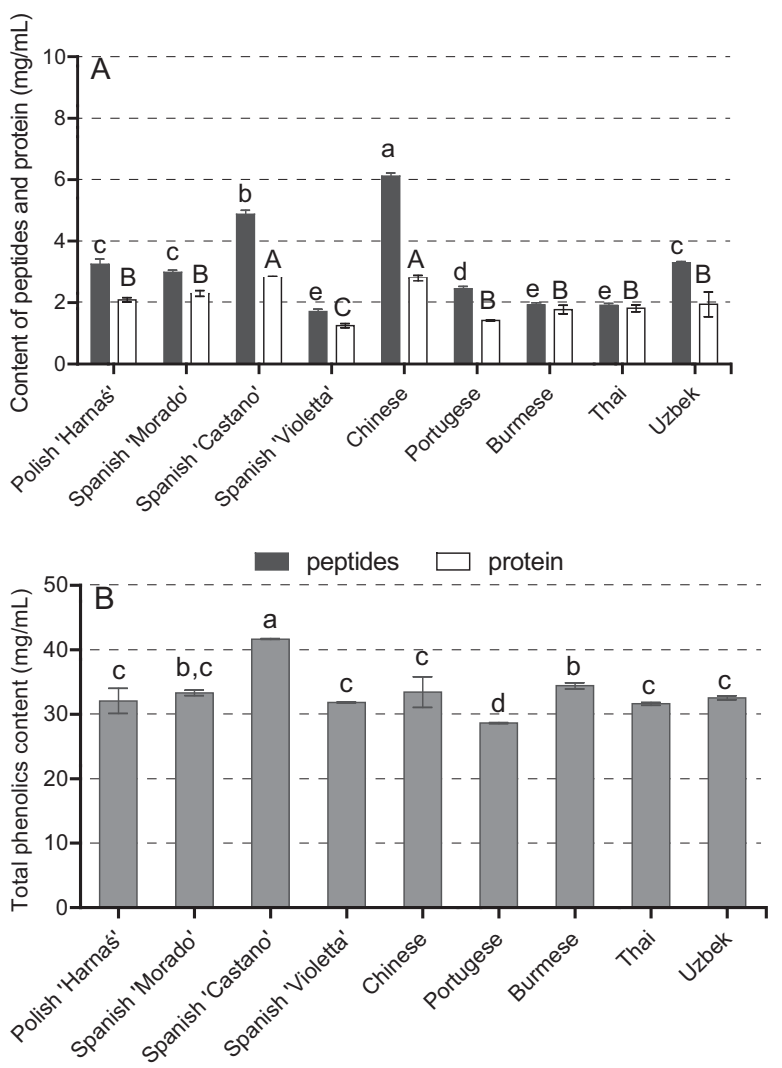

FIGURE 1. Total content of protein and peptides $(\mathrm{mg} / \mathrm{mL})$ in different garlic cultivars extracted from $1 \mathrm{~g}$ of raw garlic bulb (A).

Different lower and capital letters indicate significant differences in contents of peptides and protein, respectively $(\mathrm{p}<0.05)$. Total phenolics content $(\mathrm{mg} / \mathrm{mL})$ in different garlic cultivars extracted from $1 \mathrm{~g}$ of raw garlic bulb (B). Different lower and letters indicate significant difference $(\mathrm{p}<0.05)$. Bars represent means $\pm \mathrm{SD}(\mathrm{n}=12)$. 
TABLE 1. Content of phenolic compounds $(\mu \mathrm{g} / \mathrm{g})$ in aqueous extracts from garlic cultivars.

\begin{tabular}{|c|c|c|c|c|c|c|c|}
\hline \multicolumn{8}{|c|}{ Phenolic compounds $(\mu \mathrm{g} / \mathrm{g})$ of raw garlic } \\
\hline Garlic variety & $\begin{array}{l}\text { Gallic } \\
\text { acid }\end{array}$ & $\begin{array}{c}\text { Syringic } \\
\text { acid derivatives }\end{array}$ & $(+)$-Catechin & $\begin{array}{l}p \text {-Coumaric } \\
\text { acid }\end{array}$ & $\begin{array}{c}p \text {-Hydroxy- } \\
\text { benzoic } \\
\text { acid derivatives }\end{array}$ & Epicatechin & $\begin{array}{r}\text { Total } \\
\text { (sum) }\end{array}$ \\
\hline Polish 'Harnaś' & $1.46 \pm 0.41^{\mathrm{a}}$ & $68.19 \pm 11.10^{\mathrm{bc}}$ & $41.18 \pm 12.40^{\mathrm{abc}}$ & $1.10 \pm 0.14^{\mathrm{a}}$ & $111.81 \pm 14.29^{\text {cde }}$ & $0.00^{\mathrm{a}}$ & 223.74 \\
\hline Spanish 'Morado’ & $5.30 \pm 0.04^{c}$ & $44.63 \pm 1.98^{\mathrm{a}}$ & $95.03 \pm 6.10^{\mathrm{d}}$ & $1.60 \pm 0.57^{\mathrm{ab}}$ & $218.97 \pm 12.40^{\mathrm{f}}$ & $0.00^{\mathrm{a}}$ & 365.52 \\
\hline Spanish 'Castano’ & $7.31 \pm 0.41^{\mathrm{d}}$ & $75.21 \pm 8.45^{\mathrm{c}}$ & $38.33 \pm 0.45^{\mathrm{b}}$ & $1.05 \pm 0.07^{\mathrm{a}}$ & $118.61 \pm 1.17^{\mathrm{d}}$ & $25.68 \pm 4.25^{\mathrm{e}}$ & 266.19 \\
\hline Spanish 'Violetta' & $4.10 \pm 0.89^{\mathrm{b}}$ & $49.18 \pm 0.58^{\mathrm{a}}$ & $34.84 \pm 4.48^{\mathrm{ab}}$ & $1.50 \pm 0.71^{\mathrm{ab}}$ & $99.53 \pm 2.87^{c}$ & $12.84 \pm 6.05^{\mathrm{bcd}}$ & 201.99 \\
\hline Chinese & $16.38 \pm 2.48^{\mathrm{f}}$ & $200.02 \pm 4.68^{d}$ & $38.64 \pm 8.06^{\mathrm{b}}$ & $3.03 \pm 0.04^{c}$ & $136.03 \pm 2.35^{\mathrm{e}}$ & $0.00^{\mathrm{a}}$ & 394.10 \\
\hline Portuguese & $7.31 \pm 1.24^{\mathrm{d}}$ & $59.72 \pm 0.88^{b}$ & $26.29 \pm 1.34^{\mathrm{a}}$ & $1.55 \pm 0.78^{\mathrm{ab}}$ & $106.17 \pm 2.35^{\mathrm{c}}$ & $0.00^{\mathrm{a}}$ & 201.04 \\
\hline Burmese & $4.10 \pm 0.56^{\mathrm{b}}$ & $75.21 \pm 1.17^{\mathrm{c}}$ & $63.35 \pm 8.96^{c}$ & $2.00 \pm 0.08^{\mathrm{b}}$ & $100.36 \pm 1.17^{c}$ & $8.56 \pm 0.89^{c}$ & 253.58 \\
\hline Thai & $4.68 \pm 0.25^{b}$ & $83.48 \pm 12.86^{\mathrm{c}}$ & $31.68 \pm 2.58^{\mathrm{a}}$ & $1.00 \pm 0.02^{\mathrm{a}}$ & $59.72 \pm 6.78^{\mathrm{a}}$ & $4.71 \pm 1.45^{\mathrm{b}}$ & 185.26 \\
\hline Uzbek & $11.12 \pm 0.65^{\mathrm{e}}$ & $55.38 \pm 1.17^{\mathrm{b}}$ & $57.33 \pm 0.45^{\mathrm{c}}$ & $1.00 \pm 0.01^{\mathrm{a}}$ & $85.43 \pm 1.17^{\mathrm{b}}$ & $21.40 \pm 6.05^{\mathrm{de}}$ & 231.66 \\
\hline
\end{tabular}

Means $\pm \mathrm{SD}(\mathrm{n}=9)$, in columns, for the respective components followed by different lower case letters are significantly different at $\mathrm{p}<0.05$.

The content of total phenolics, expressed as mg of gallic acid equivalents extracted from $1 \mathrm{~g}$ of raw garlic, varied between 28.65 and $41.66 \mathrm{mg} / \mathrm{mL}$ for Portuguese and Spanish 'Castano' cultivars, respectively. No significant differences were found between Polish 'Harnaś', Chinese, Spanish 'Morado', Spahish 'Violetta', Thai, and Uzbek cultivars. The content of total phenolics for those cultivars ranged between 31.64 and $34.42 \mathrm{mg} / \mathrm{mL}$ (Figure 1B).

\section{Quantitative and qualitative analysis of phenolic compounds by high performance liquid chromatography}

Due to the significant differences in the content of total phenolics, the aqueous extract from garlic varieties were further analyzed for contents of six phenolic compounds using high performance liquid chromatography (Table 1). The highest contents of phenolic compounds were found in the extracts from Chinese and Spanish 'Morado' garlic cultivars (394.10 $\mu \mathrm{g} / \mathrm{g}$ and $365.52 \mu \mathrm{g} / \mathrm{g}$ of raw garlic, respectively). From among the analyzed phenolics, garlic extracts contained the highest amount of syringic and $p$-hydroxybenzoic acids derivatives. . In addition, Chinese cultivar contained the highest amount of gallic acid $(16.38 \mu \mathrm{g} / \mathrm{g})$ and $p$-cumaric acid $(3.03 \mu \mathrm{g} / \mathrm{g})$. The analyzed extracts contained also significant amounts of flavan-3-ols, such as $(+)$-catechin and epicatechin. Interestingly, five out of the nine analyzed garlic extracts contained significant amounts of epicatechin, whereas Polish 'Harnaś', Chinese, Portuguese and Spanish 'Morado' garlic cultivars did not contain detectable amounts of that phenolic compound.

\section{Comparison of the antioxidant activity of garlic extracts}

\section{Free radical scavenging capacity}

The free radical scavenging activity was compared with the content of total phenolic compounds and expressed as the $\mathrm{IC}_{50}$ value, defined as $\mu \mathrm{g}$ of phenolics in the extract from $1 \mathrm{~g}$ of raw garlic which are able to scavenge $50 \%$ of the analyzed free radicals (Table 2). The antioxidant potential of garlic extracts was evaluated using DPPH ${ }^{*}$ and $\mathrm{ABTS}^{\cdot+}$ stable free radical scavenging assays. In both assays, the highest radical scavenging activity was observed for the extract from Chinese garlic, i.e. $4.63 \mu \mathrm{g} / \mathrm{mL}$ for DPPH ${ }^{*}$ and $0.43 \mu \mathrm{g} / \mathrm{mL}$ for $\mathrm{ABTS}^{+\cdot}$ (Table 2). In addition, the lowest $\mathrm{IC}_{50}$ values for $\mathrm{DPPH}^{\bullet}$ scavenging were noted for Portuguese garlic extracts $(4.88 \mu \mathrm{g} / \mathrm{mL})$. The Polish 'Harnaś' and Spanish 'Castano' cultivars had relatively low antioxidant activity ( 6.52 and $7.59 \mu \mathrm{g} / \mathrm{mL}$, respectively) against $\mathrm{DPPH}^{\cdot}$. The aqueous extract from Spanish 'Morado' garlic extract possessed the lowest $\mathrm{ABTS}^{\cdot+}$ scavenging potential $(1.68 \mu \mathrm{g} / \mathrm{mL})$ (Table 2).

\section{Ion chelation activity}

The ability to chelate $\mathrm{Fe}^{2+}$ and $\mathrm{Cu}^{2+}$ ions was compared among the analyzed aqueous extracts of nine garlic cultivars. The obtained data are displayed as the $\mathrm{IC}_{50}$ values, defined as the concentration of phenols in each extract from raw garlic that is required to chelate $50 \%$ of $\mathrm{Fe}^{2+}$ or $\mathrm{Cu}^{2+}$ ions (Table 2). The highest $\mathrm{Fe}^{2+}$ chelation ability was noted for garlic cultivated in Poland ('Harnaś') and Burma, with the lowest $\mathrm{IC}_{50}$ values of 0.04 and $0.03 \mu \mathrm{g} / \mathrm{mL}$, respectively. Thai, Portuguese and three Spanish garlic cultivars possessed relatively low $\mathrm{Fe}^{2+}$ chelating activity, with the $\mathrm{IC}_{50}$ values ranging between 0.42 and $0.90 \mu \mathrm{g} / \mathrm{mL}$ (Table 2). The highest $\mathrm{Cu}^{2+}$ chelating ability was noted for Chinese and Polish 'Harnaś' garlic extract (14.90 and $16.58 \mu \mathrm{g} / \mathrm{mL}$, respectively). The Portuguese, Thai and Uzbek cultivars were comparable $(21.41-25.14 \mu \mathrm{g} / \mathrm{mL}$, respectively), whereas the lowest $\mathrm{Cu}^{2+}$ chelating activity was measured for Burmese garlic $(76.65 \mu \mathrm{g} / \mathrm{mL})$ (Table 2).

\section{Cytotoxicity of aqueous extracts from different garlic varieties in vitro}

In the presence of Polish 'Morado', Burmese, Thai and Uzbek garlic extracts in the culture medium, the morphology and number of viable cells did not change significantly, even at the higher tested concentration of the extract $(1 \mathrm{mg} / \mathrm{mL})$. The morphology and the number of cells grown in the presence of the other five garlic extracts was significantly impaired. 
TABLE 2. $\mathrm{IC}_{50}$ value for antiradical activity against $\mathrm{DPPH}^{\bullet}$ and $\mathrm{ABTS}^{*+}$ and the ability to chelate $\mathrm{Fe}^{2+}$ and $\mathrm{Cu}^{2+}$ ions determined for garlic extracts $(\mu \mathrm{g} / \mathrm{mL})$.

\begin{tabular}{|c|c|c|c|c|}
\hline \multirow{2}{*}{ Alium sativum extracts } & $\mathrm{DPPH}^{\bullet}$ & $\mathrm{ABTS}^{\cdot+}$ & $\mathrm{Fe}^{+2}$ & $\mathrm{Cu}^{+2}$ \\
\hline & \multicolumn{4}{|c|}{$\mathrm{IC}_{50}(\mu \mathrm{g} / \mathrm{mL})$} \\
\hline Polish 'Harnaś' & $6.52 \pm 0.06^{c}$ & $0.68 \pm 0.0^{\mathrm{b}}$ & $0.04 \pm 0.01^{\mathrm{a}}$ & $16.58 \pm 0.45^{\mathrm{a}, \mathrm{b}}$ \\
\hline Spanish 'Morado' & $5.44 \pm 0.18^{b}$ & $1.68 \pm 0.09^{\mathrm{e}}$ & $0.47 \pm 0.08^{\mathrm{c}, \mathrm{d}}$ & $28.94 \pm 0.36^{a, b, c}$ \\
\hline Spanish 'Castano' & $7.59 \pm 0.05^{\mathrm{d}}$ & $0.78 \pm 0.05^{\mathrm{c}}$ & $0.64 \pm 0.08^{e}$ & $32.33 \pm 3.37^{\mathrm{b}, \mathrm{c}}$ \\
\hline Spanish 'Violetta' & $5.49 \pm 0.05^{\mathrm{b}}$ & $0.68 \pm 0.01^{\mathrm{b}, \mathrm{c}}$ & $0.42 \pm 0.08^{c}$ & $42.82 \pm 2.54^{c}$ \\
\hline Chinese & $4.63 \pm 0.05^{\mathrm{a}}$ & $0.43 \pm 0.0^{\mathrm{a}}$ & $0.10 \pm 0.02^{\mathrm{a}, \mathrm{b}}$ & $14.90 \pm 1.08^{\mathrm{a}}$ \\
\hline Portuguese & $4.88 \pm 0.06^{\mathrm{a}}$ & $0.93 \pm 0.02^{\mathrm{d}}$ & $0.53 \pm 0.01^{\mathrm{d}}$ & $21.41 \pm 0.88^{\mathrm{a}, \mathrm{b}}$ \\
\hline Burmese & $5.56 \pm 0.05^{\mathrm{b}}$ & $0.73 \pm 0.02^{\mathrm{b}, \mathrm{c}}$ & $0.03 \pm 0.02^{a}$ & $76.65 \pm 1.24^{\mathrm{d}}$ \\
\hline Thai & $5.53 \pm 0.12^{\mathrm{b}}$ & $0.70 \pm 0.02^{\mathrm{b}, \mathrm{c}}$ & $0.90 \pm 0.08^{\mathrm{f}}$ & $22.05 \pm 2.32^{\mathrm{a}, \mathrm{b}}$ \\
\hline Uzbek & $5.54 \pm 0.05^{\mathrm{b}}$ & $0.66 \pm 0.02^{\mathrm{b}, \mathrm{c}}$ & $0.20 \pm 0.06^{\mathrm{b}}$ & $25.14 \pm 1.57^{\mathrm{a}, \mathrm{b}}$ \\
\hline Positive control & $0.87^{1} \pm 0.08$ & $0.10^{1} \pm 0.07$ & $0.45^{2} \pm 0.02$ & $0.22^{2} \pm 0.45$ \\
\hline
\end{tabular}

Means \pm SD $(n=12)$. ${ }^{1}$ ascorbic acid $(\mathrm{AA})$ was used as a positive control; ${ }^{2}$ ethylenedinitrilotetraacetic acid (EDTA) was used as a positive control. Different lower case letters in the same column indicate significant difference $(\mathrm{p}<0.05)$.

Interestingly, microscopic examination of the cells cultured in the presence of Uzbek garlic extract revealed the presence of crystals characteristic for oxalate salts (Figure 2, indicated by arrows). The chemical nature of the observed crystals requires further analysis, however their presence was not detected in any other analyzed garlic extract.

The number of viable cells following garlic extracts treatment was quantified by measuring the absorbance of Neutral Red released from the cells during incubation with an acidified ethanol solution. The absorbance of control cells was set to $100 \%$ and used to calculate the percentage of cellular proliferation and/or viability following the treatment with different amounts of garlic extracts. Statistical analysis of cellular viability for the highest analyzed extract concentrations revealed that Spanish 'Morado' and Chinese garlic extracts were highly antiproliferative and/or cytotoxic for human skin fibroblasts as they reduced proliferation and/or viability to $10-30 \%$ of the control level (Figure 3).

The $1 \mathrm{mg} / \mathrm{mL}$ of Portuguese, Spanish 'Castano' and Spanish 'Violetta' garlic extracts decreased the number of fibroblasts to $70 \%$, whereas the extract from Thai garlic increased the number of cells to $130 \%$ (Figure 3).

\section{DISCUSSION}

Garlic (Allium sativum L.) is a popular plant cultivated worldwide due to its characteristic, spicy taste and medical properties that have been recognized for thousands of years. In the ranking of total phenolics content of 23 commonly consumed vegetables garlic has been ranked second [Vinson et al., 1998]. Phenolic compounds and other phytoconstituents as plant-derived proteins or peptides show a significant bioactivity [Durak et al., 2013; Elias et al., 2008; Karaś et al., 2015]. Although most antioxidant activities of plant extracts are connected with phenolic compounds. However, nowadays there has been a growing number of evidence showing that other compounds, like proteins and peptides, can also possess a significant antioxidant activity [Elias et al., 2008; Karaś et al., 2015]. Our results indicated that the content of peptides and proteins was highly variable. The highest protein content was found in Chinese garlic and the lowest one in Spanish 'Violetta' garlic. Furthermore, within one country, the protein content in garlic cloves was very diverse. Spanish 'Castano' garlic contained 2.5 times more proteins than Spanish 'Violetta' garlic. However, the total content of phenolic compounds was similar among all the analyzed cultivars of garlic. Interestingly, the final concentration of total phenolics depends indirectly on the size of a garlic clove [Beato et al., 2011]. It is known that the contents of phenolic compounds and proteins in garlic cultivars are determined by genetic, agronomic, and environmental factors. Therefore we made a chromatographic analysis of plant extracts to identify the content of phenolic compounds. Garlic extracts were analyzed for the content of six phenolics abundant in plants, including phenolic acids (gallic, syringic, $p$-coumaric and $p$-hydroxybenzoic) and flavonoids (catechin and epicatechin). All the studied extracts contained significant amounts of phenolic acids, especially syringic acid and $p$-hydroxybenzoic acid derivatives, whereas epicatechin was not detected in four out of the nine analyzed extracts. The obtained results are consistent with previously published data, indicating that the content of phenolic compounds varies in different garlic cultivars [Gorinstein et al., 2005; Kim et al., 2013; Lu et al., 2011; Miean \& Mohamed, 2001]. Beato et al. [2011] reported that garlic from Spain contained high amounts of $p$-hydroxybenzoic acid and no of syringic acid. Our data showed that Spanish 'Morado' and Chinese garlic cultivars had the highest content of $p$-hydroxybenzoic acid and that the lowest content of syringic acid was noted in Spanish 'Morado' and Spanish 'Violetta' cultivars. In our study, a correlation between a high content of $p$-hydroxybenzoic and a low content of syringic acids occurred only in the case of Spanish 


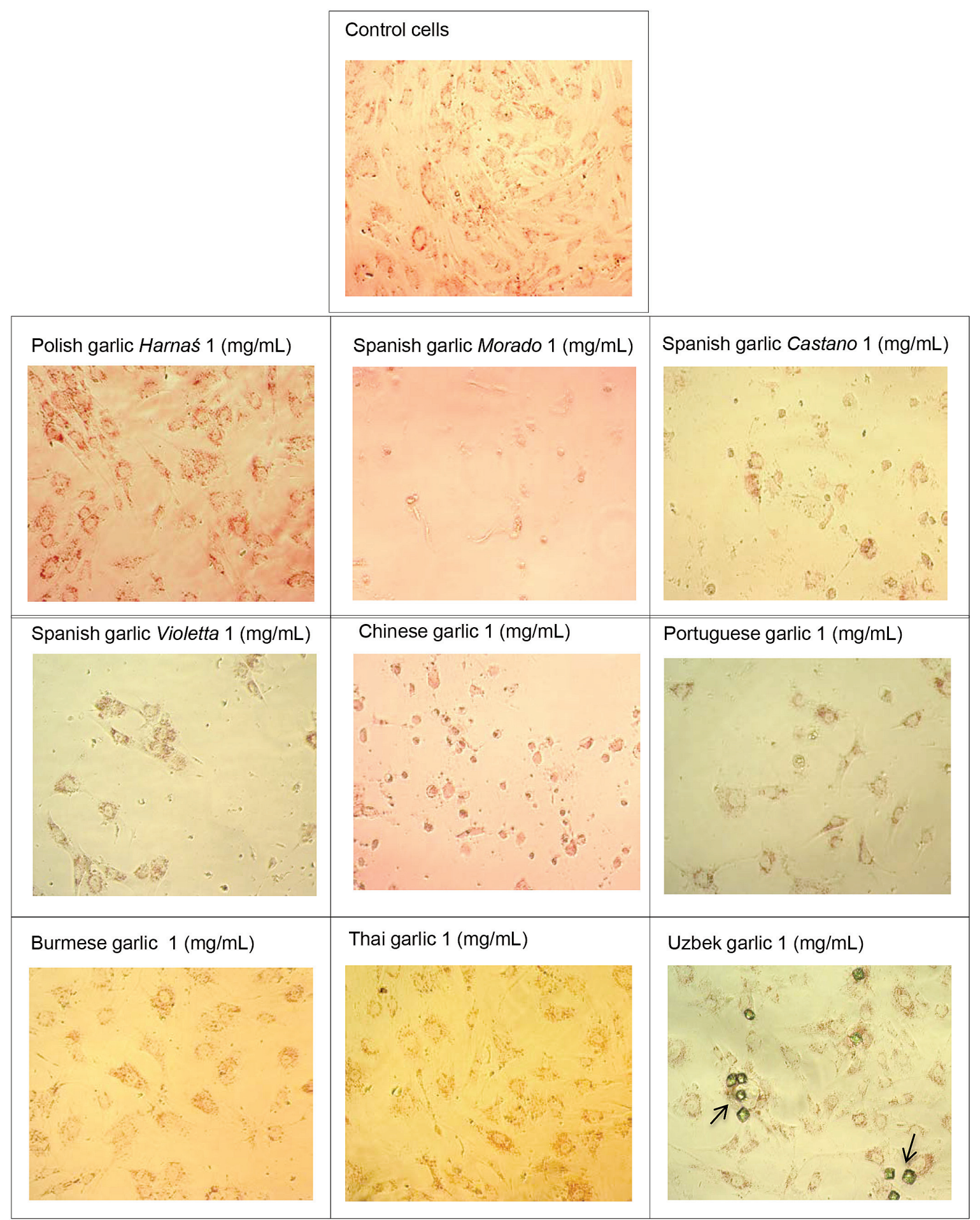

FIGURE 2. The effect of garlic extracts ( $1 \mathrm{mg} / \mathrm{mL}$ ) from Poland ('Harnaś' variety), Spain ('Castano', 'Morado' and 'Violetta' varieties), China, Portugal, Burma, Thailand and Uzbekistan on Neutral Red uptake after $48 \mathrm{~h}$.

In cells exposed to Uzbek garlic extract, the presence of crystals characteristic for oxalate salts is indicated with arrows. Photomicrographs are shown at $200 \times$ magnification.

'Morado' cultivar. The hydroxybenzoic acid derivatives, especially $p$-hydroxybenzoic acid, have been consistently associated with a reduced risk of cardiovascular diseases, cancer and other chronic diseases [Rocha et al., 2012; Spencer et al., 2008]. In our study, we did not detect the epicatechin flavonoid in extracts from Polish 'Harnaś', Spanish 'Morado', Chinese and Portuguese garlic cultivars. Data reported by Miean
\& Mohamed [2001] indicated that a high content of quercetin in garlic extracts. However, this flavonoid was not detected in any garlic extracts tested by other authors [Beato et al., 2011; Gorinstein et al., 2005]. This data suggests that some regional varieties of garlic may have unique components.

The mechanisms of plant protein-dependent antioxidant activity involve the scavenging of free radicals, inactivation 


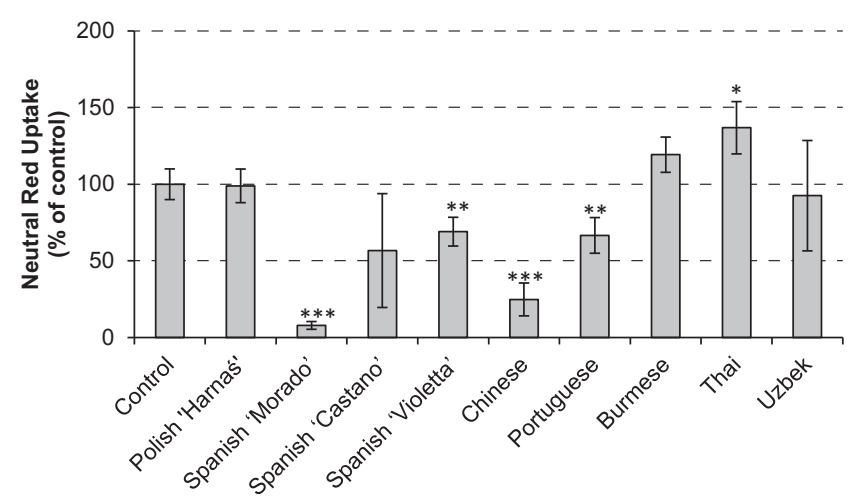

FIGURE 3. The effect of garlic extracts ( $1 \mathrm{mg} / \mathrm{mL})$ from Poland ('Harnaś' variety), Spain ('Castano', 'Morado' and 'Violetta' varieties), China, Portugal, Burma, Thailand and Uzbekistan on Neutral Red uptake after 48 h.

Means $\pm \mathrm{SD}, \mathrm{n}=32,{ }^{*} \mathrm{p}<0.05 ;{ }^{* *} \mathrm{p}<0.01$ and ${ }^{* * *} \mathrm{p}<0.001$ vs. the control.

of ROS, chelation of pro-oxidative transition metal ions, and reduction of hydroperoxidase [Durak et al., 2013; Erdmann et al., 2008; Park et al., 2005]. Various contents of phenolic compounds, proteins and peptides in aqueous extracts from the analyzed garlic cultivars suggested significant differences in their biological activity, especially their antioxidant potential. Previous studies demonstrated that one of the important health benefits of garlic was the reduction of ROS generation and minimization of their negative impact on human health [Amagase, 2006]. We decided to evaluate the antioxidant potential of garlic extracts using $\mathrm{DPPH}^{\bullet}$ and $\mathrm{ABTS}^{+\bullet}$ scavenging assays. In both $\mathrm{DPPH}^{\bullet}$ and $\mathrm{ABTS}^{+}{ }^{\bullet}$ scavenging assays the lowest $\mathrm{IC}_{50}$ values, indicating the highest antiradical activity, were observed for Chinese garlic extract, which had one of the highest contents of $p$-hydroxybenzoic acid derivatives. The lowest free radical scavenging potential was manifested by Spanish 'Castano' (DPPH• assay) and 'Morado' (ABTS • ${ }^{*}$ ) garlic cultivars. Interestingly, the antioxidant capacity of garlic extracts detected using the $\mathrm{ABTS}^{+}{ }^{+}$scavenging assay was significantly higher in comparison with the DPPH${ }^{\bullet}$ assay. The earlier study has demonstrated that higher scavenging of $\mathrm{ABTS}^{\bullet+}$ was observed for phenolics with three or more hydroxyl groups [Biskup et al., 2013]. The antioxidant activity depends on the number and position of the hydroxyl groups of the aromatic ring binding site and the type of a substituent [Ishige et al., 2001]. These data suggest that the ABTS •+ assay may be more sensitive to detect and compare the free radical scavenging potential of aqueous garlic extracts.

In addition to the scavenging of free radicals, plant-derived compounds were shown to reduce ROS level by chelating transition metal ions, such as $\mathrm{Fe}^{2+}$ and $\mathrm{Cu}^{2+}$ [Durak et al., 2013; Iwaniak \& Minkiewicz, 2007]. $\mathrm{Fe}^{2+}$ and $\mathrm{Cu}^{2+}$ participate in the synthesis of superoxide anion and hydroxyl radicals via the Fenton reaction. Chelation of these ions by plant antioxidants prevents the generation of hydroxyl radicals and significantly reduces the negative impact of oxidative stress [Gordon, 1990; Lee et al., 2012]. In our research, $\mathrm{Fe}^{2+}$ and $\mathrm{Cu}^{2+}$ chelating ability revealed significant differences between garlic cultivars. The aqueous extract from Polish 'Harnaś' garlic effectively chelated both $\mathrm{Fe}^{2+}$ and $\mathrm{Cu}^{2+}$ ions, whereas Burmese garlic extract was effective in $\mathrm{Fe}^{2+}$ but not $\mathrm{Cu}^{2+}$ che- lation. In general, the analyzed garlic extracts displayed a significantly lower ability to chelate $\mathrm{Cu}^{2+}$ than $\mathrm{Fe}^{2+}$ ions. The significant ion chelating ability of the tested extracts suggested that in human diet aqueous extracts from the analyzed garlic cultivars may be a valuable source of phenolics antioxidant activity. Generally, garlic cultivars which contained relatively high amounts of $p$-hydroxibenzoic acid derivatives were characterized by high ion chelating activity. Earlier studies show that the antioxidant capability of hydroxycinnamic acids in $v i$ tro could be expressed by decreased malondialdehyde formation in lipid peroxidation and scavenging the superoxide anion or decreased rates of hydroxyl radical formation [Laranjinha et al., 1994]. The obtained results support the previously published findings, indicating that aqueous garlic extracts prevent $\mathrm{Fe}^{2+}$ and $\mathrm{Cu}^{2+}$-induced low density lipoprotein (LDL) oxidation [Lewin \& Popov, 1994; Oboh et al., 2013; Ou et al., 2003; Pedraza-Chaverrí et al., 2004].

The high content of phenolic compounds in the analyzed garlic extracts as well as their significant antioxidant activity indicate that some garlic cultivars are better sources of bioactive ingredients for food supplements and pharmaceuticals. The chemopreventive properties of phenolic compounds are generally believed to reflect their ability to scavenge endogenous ROS. However, plant-derived phenolics may exhibit also the pro-oxidant action, which may be an important mechanism for their anticancer and apoptosis-inducing properties [Spencer et al., 2008]. The phenomenon of ROS-mediated cell death has been recently observed in human tongue squamous carcinoma cell line (SCC-15) exposed to garlic extracts [Szychowski et al., 2016]. In the case of garlic, a high content of biologically-active components, such as phenolic compounds, may also increase the toxicity of garlic extracts [Oboh et al. 2013].

Results obtained in our study showed that the lowest antiproliferative effect on normal human fibroblast was found in extracts from Polish 'Harnaś', Burmese and Uzbek cultivars. Interestingly, Polish cultivar 'Harnaś' exhibited an opposite effect on the SCC-15 cancer cell line [Szychowski et al., 2016]. Moreover, in our study, the Chinese and Spanish 'Morado' garlic extracts had the highest antiproliferative effect. A similar effect of the extract from Spanish cultivar 'Morado' was observed in the SCC-15 cell line [Szychowski et al., 2016]. These data suggest that garlic extracts can be toxic to both normal and cancer cells. The significant differences in fibroblasts proliferation which were demonstrated in the presence of aqueous extracts from the analyzed garlic cultivars are most likely due to the differences in the content of biologically-active phytochemicals, especially phenolic compounds. Azadi et al. [2009] reported that $1.00 \mathrm{mg} / \mathrm{mL}$ of chloroformic extract of Allium hirtifolium was non-toxic to normal mouse fibroblast cell line L929. Moreover, an earlier study showed that garlic and onion, which both belong to the Allium hirtifolium genus, exhibited significant cytoprotective effects on normal cells [Shrivastava \& Ganesh, 2010]. Ismail et al. [2013] demonstrated that $1.50 \mathrm{mg} / \mathrm{mL}$ extract from Allium hirtifolium was safe for mammalian cells. Our results showed that some of the studied garlic extracts did not suppress normal cell proliferation. However, we cannot exclude their cytotoxic effects on other cell types. Due to the high content of phenolic 
compounds, both antiproliferative and cytotoxic properties of garlic extracts are mainly observed in the case of cancer cell lines [Gorinstein et al., 2005].

\section{CONCLUSION}

To conclude, our results show diverse contents of protein and phenolic compounds in garlic bulbs from different regional cultivars. The obtained results could help to choose the varieties of garlic which contain significant amounts of active compounds, have important antioxidant properties and display low antiproliferative effect and/or low cytotoxicity against normal human skin fibroblast BJ. More research is, however, required to better understand the cytotoxic properties of garlic extracts.

\section{ACKNOWLEDGEMENTS}

This study was supported by statutory funds from the University of Information Technology and Management in Rzeszow, Poland (DS 503-07-02-08).

\section{CONFLICT OF INTERESTS}

Authors declare no conflict of interest.

\section{REFERENCES}

1. Adler-Nissen J., Determination of the degree of hydrolysis of food protein hydrolysates by trinitrobenzenesulfonic acid. J. Agric. Food Chem., 1979, 27, 1256-1262.

2. Amagase H., Clarifying the real bioactive constituents of garlic. J. Nutr., 2006, 136, 716S-725S.

3. Arts I.C.W., Hollman P.C.H., Polyphenols and disease risk in epidemiologic studies. Am. J. Clin. Nutr., 2005, 81, 317S-325S.

4. Azadi H.G., Riazi G.H., Ghaffari S.M., Ahmadian S., Khalife T.J., Effects of Allium hirtifolium (Iranian shallot) and its allicin on microtubule and cancer cell lines. African J. Biotechnol., 2009, 8, 5030-5037.

5. Beato V.M., Orgaz F., Mansilla F., Montaño A., Changes in phenolic compounds in garlic (Allium sativum L.) owing to the cultivar and location of growth. Plant Foods Hum. Nutr., 2011, 66, 218-223.

6. Belloir C., Singh V., Daurat C., Siess M.H., Le Bon A. M., Protective effects of garlic sulfur compounds against DNA damage induced by direct- and indirect-acting genotoxic agents in HepG2 cells. Food Chem. Toxicol., 2006, 44, 827-834.

7. Bhandari P., Garlic (Allium sativum L.): A review of potential therapeutic applications. Int. J. Green Pharm., 2012, 6, 2, 118-129.

8. Biskup I., Golonka I., Gamian A., Sroka Z., Antioxidant activity of selected phenols estimated by ABTS and FRAP methods. Postępy Hig. Med. Doświad., 2013, 67, 958-963.

9. Bradford M.M., A rapid and sensitive method for the quantitation of microgram quantities of protein utilizing the principle of protein-dye binding. Anal. Biochem., 1976, 72, 248-254.

10. Brand-Williams W., Cuvelier M.E., Berset C., Use of a free radical method to evaluate antioxidant activity. LWT - Food Sci. Technol., 1995, 28, 25-30.
11. Dai J., Mumper R.J., Plant phenolics: Extraction, analysis and their antioxidant and anticancer properties. Molecules, 2010, 15, 7313-7352.

12. Decker E.A., Welch B., Role of ferritin as a lipid oxidation catalyst in muscle food. J. Agric. Food Chem., 1990, 38, 674-677.

13. Durak A., Baraniak B., Jakubczyk A., Świeca M., Biologically active peptides obtained by enzymatic hydrolysis of Adzuki bean seeds. Food Chem., 2013, 141, 2177-2183.

14. Elias R.J., Kellerby S.S., Decker E.A., Antioxidant activity of proteins and peptides. Crit. Rev. Food Sci. Nutr., 2008, 48, 430-441.

15. Erdmann K., Cheung B.W.Y., Schröder H., The possible roles of food-derived bioactive peptides in reducing the risk of cardiovascular disease. J. Nutr. Biochem., 2008, 19, 643-654.

16. Gordon M.H., The Mechanism of Antioxidant Action In Vitro. 1990, in: Food Antioxidants. Springer Netherlands, Dordrecht, pp. 1-18.

17. Gorinstein S., Drzewiecki J., Leontowicz H., Leontowicz M., Najman K., Jastrzebski Z., Zachwieja Z., Barton H., Shtabsky B., Katrich E., Trakhtenberg S., Comparison of the bioactive compounds and antioxidant potentials of fresh and cooked Polish, Ukrainian, and Israeli garlic. J. Agric. Food Chem., 2005, 53, 2726-2732.

18. Ishige K., Schubert D., Sagara Y., Flavonoids protect neuronal cells from oxidative stress by three distinct mechanisms. Free Radic. Biol. Med., 2001, 30, 433-446.

19. Ismail S., Jalilian F.A., Talebpour A.H., Zargar M., Shameli K., Sekawi Z., Jahanshiri F., Chemical composition and antibacterial and cytotoxic activities of Allium hirtifolium Boiss. Biomed Res. Int., 2013, 2013, art no. 696835.

20. Iwaniak A., Minkiewicz P., Proteins as the source of physiologically. Acta Sci. Pol. Technol. Aliment., 2007, 6, 5-15.

21. Karaś M., Baraniak B., Rybczyńska K., Gmiński J., Gaweł-Bęben K., Jakubczyk A., The influence of heat treatment of chickpea seeds on antioxidant and fibroblast growth-stimulating activity of peptide fractions obtained from proteins digested under simulated gastrointestinal conditions. Int. J. Food Sci. Technol., 2015, 50, 2097-2103.

22. Kim J.S., Kang O.J., Gweon O.C., Comparison of phenolic acids and flavonoids in black garlic at different thermal processing steps. J. Funct. Foods, 2013, 5, 80-86.

23. Kohda K., Goda H., Itoh K., Samejima K., Fukuuchi T., Aged garlic extract reduces ROS production and cell death induced by 6-hydroxydopamine through activation of the Nrf2-ARE pathway in SH-SY5Y cells. Pharmacol. Pharm., 2013, 4, 1, 31-40.

24. Laranjinha J.A., Almeida L.M., Madeira V.M., Reactivity of dietary phenolic acids with peroxyl radicals: antioxidant activity upon low density lipoprotein peroxidation. Biochem. Pharmacol., 1994, 48, 487-494.

25. Lee J.-C., Son Y.-O., Pratheeshkumar P., Shi X., Oxidative stress and metal carcinogenesis. Free Radic. Biol. Med., 2012, 53, 742-757.

26. Lemar K.M., Turner M.P., Lloyd D., Garlic (Allium sativum) as an anti-Candida agent: a comparison of the efficacy of fresh garlic and freeze-dried extracts. J. Appl. Microbiol., 2002, 93, 398-405.

27. Lewin G., Popov I., Antioxidant effects of aqueous garlic extract. 2nd communication: Inhibition of the $\left.\mathrm{Cu}^{(2+}\right)$-initiated oxidation of low density lipoproteins. Arzneimittelforschung - Drug Res., 1994, 44, 604-607. 
28. Lu X., Ross C.F., Powers J.R., Aston D.E., Rasco B.A., Determination of total phenolic content and antioxidant activity of garlic (Allium sativum) and elephant garlic (Allium ampeloprasum) by attenuated total reflectance-Fourier transformed infrared spectroscopy. J. Agric. Food Chem., 2011, 59, 5215-5221.

29. Meriga B., Mopuri R., MuraliKrishna T., Insecticidal, antimicrobial and antioxidant activities of bulb extracts of Allium sativum. Asian Pac. J. Trop. Med., 2012, 5, 391-395.

30. Miean K.H., Mohamed S., Flavonoid (myricetin, quercetin, kaempferol, luteolin, and apigenin) content of edible tropical plants. J. Agric. Food Chem., 2001, 49, 3106-3112.

31. Oboh G., Akinyemi A.J., Ademiluyi A.O., Inhibitory effect of phenolic extract from garlic on angiotensin-1 converting enzyme and cisplatin induced lipid peroxidation - in vitro. Int. J. Biomed. Sci., 2013, 9, 98-106.

32. Ou C.-C., Tsao S.-M., Lin M.-C., Yin M.-C., Protective action on human LDL against oxidation and glycation by four organosulfur compounds derived from garlic. Lipids, 2003, 38, 219-224.

33. Park E.Y., Murakami H., Mori T., Matsumura Y., Effects of protein and peptide addition on lipid oxidation in powder model system. J. Agric. Food Chem., 2005, 53, 137-144.

34. Pedraza-Chaverrí J., Gil-Ortiz M., Albarrán G., Barbachano-Esparza L., Menjívar M., Medina-Campos O.N., Garlic's ability to prevent in vitro $\mathrm{Cu}^{2+}$-induced lipoprotein oxidation in human serum is preserved in heated garlic: effect unrelated to $\mathrm{Cu}^{2+}$-chelation. Nutr. J., 2004, 3, art. no. 10.

35. Petrovska B., Cekovska S., Extracts from the history and medical properties of garlic. Pharmacogn. Rev., 2010, 4, 106-110.

36. Re R., Pellegrini N., Proteggente A., Pannala A., Yang M., Rice-Evans C., Antioxidant activity applying an improved ABTS radical cation decolorization assay. Free Radic. Biol. Med., 1999, 26, 1231-1237.
37. Repetto G., del Peso A., Zurita J.L., Neutral red uptake assay for the estimation of cell viability/cytotoxicity. Nat. Protoc., 2008, 3, $1125-1131$.

38. Rocha L.D., Monteiro M.C., Teodoro A.J., Anticancer properties of hydroxycinnamic acids - a review. Cancer Clin. Oncol., 2012, 1, 109-121.

39. Shrivastava S., Ganesh N., Tumor inhibition and cytotoxicity assay by aqueous extract of onion (Allium cepa) \& Garlic (Allium sativum): An in-vitro analysis. Int. J. Phytomed., 2010, 2, 80-84.

40. Singleton V.L., Rossi J.A., Colorimetry of total phenolics with phosphomolybdic-phosphotungstic acid reagents. Am. J. Enol. Vitic. 1965, 16, 144-158.

41. Spencer J.P.E., Abd El Mohsen M.M., Minihane A.-M., Mathers J.C., Biomarkers of the intake of dietary polyphenols: strengths, limitations and application in nutrition research. Br. J. Nutr., 2008, 99, 12-22.

42. Swieca M., Baraniak B., Nutritional and antioxidant potential of lentil sprouts affected by elicitation with temperature stress. J. Agric. Food Chem., 2014, 62, 3306-3313

43. Szychowski K.A., Binduga U.E., Rybczyńska-Tkaczyk K., Leja M.L., Gmiński J., Cytotoxic effects of two extracts from garlic (Allium sativum L.) cultivars on the human squamous carcinoma cell line SCC-15. Saudi J Biol Sci. 2016, DOI: 10.1016/j. sjbs.2016.10.005 (in press).

44. Torres-Fuentes C., Alaiz M., Vioque J., Affinity purification and characterisation of chelating peptides from chickpea protein hydrolysates. Food Chem., 2011, 129, 485-490.

45. Vinson J.A., Hao Y., Su X., Zubik L., Phenol antioxidant quantity and quality in foods: vegetables. J. Agric. Food Chem., 1998, 46, 3630-3634.

Submitted: 5 June 2016. Revised 8 October 2016. Accepted: 15 November 2016. Published on-line: 17 March 2017. 
